\title{
Cerebral Palsy: Parental Stress of Caregivers
}

\author{
Mayara Barbosa Sindeaux Lima \\ Edson Marcos Leal Soares Ramos ${ }^{2,3}$ \\ Fernando Augusto Ramos Pontes ${ }^{2}$ \\ Simone Souza da Costa Silva \\ ${ }^{1}$ Universidade Federal do Sul e Sudeste do Pará, Marabá, Pará, Brasil \\ ${ }^{2}$ Universidade Federal do Pará, Belém, Pará, Brasil \\ ${ }^{3}$ Universidade de Cabo Verde, Praia, Ilha de Santiago, Cabo Verde
}

\begin{abstract}
The aim of this research was to investigate indicators of parental stress among caregivers of children with Cerebral Palsy. The study covered a total of 132 participants who responded to the following instruments: Sociodemographic Inventory, Gross Motor Function Classification System, and Parental Stress Index (PSI). Data were analyzed using descriptive statistics. The sample was composed mainly of mothers $(97 \%)$; most of the children were classified under the most severe levels of motor impairment (61\%). Regarding the PSI, almost half of the sample experienced high levels of parental stress (46.2\%). The PSI domain with the highest percentage of caregivers with high stress was Parental Distress $(60.6 \%)$. Most caregivers prioritize the needs of the child with Cerebral Palsy over their own needs more than they expected $(90 \%)$. These results may support intervention strategies aimed at minimizing parental stress.

Keywords: cerebral palsy; children; caregivers; stress
\end{abstract}

Paralisia Cerebral: Estresse Parental de Cuidadores

\section{Resumo}

O objetivo desta pesquisa foi investigar indicadores de estresse parental entre cuidadores de crianças com paralisia cerebral. Participaram 132 cuidadores que responderam aos instrumentos: Inventário Sociodemográfico, Sistema de Classificação da Função Motora Grossa e Índice de Estresse Parental (PSI). Os dados foram analisados por meio de estatística descritiva. A amostra foi composta principalmente por mães (97\%); a maioria das crianças apresentou grave comprometimento motor (61\%). Em relação ao PSI, quase metade dos cuidadores apresentou altos níveis de estresse parental (46,2\%). O domínio do PSI com maior percentual de cuidadores com alto estresse foi o Sofrimento Parental (60,6\%). A maioria dos cuidadores prioriza as necessidades da criança com PC em detrimento das suas mais do que esperava (90\%). Esses resultados podem subsidiar estratégias de intervenção com vistas a minimizar o estresse parental.

Palavras-chave: paralisia cerebral, crianças, cuidadores, estresse

\section{Parálisis Cerebral: Estrés Paternal de Cuidadores}

\section{Resumen}

El objetivo de esta investigación fue estudiar indicadores de estrés parental entre los cuidadores de niños con Parálisis Cerebral. Participaron del estudio un total de 132 cuidadores que contestaron a los siguientes instrumentos: Inventario Sociodemográfico, Sistema de Clasificación de la Función Motora Gruesa e Índice de Estrés Parental (PSI). Los datos fueron analizados mediante estadística descriptiva. La muestra fue compuesta principalmente por madres (97\%); la mayoría de los niños se clasificaron en los niveles más graves de discapacidad motora (61\%). En relación al PSI, casi la mitad de los cuidadores presentó niveles elevados de estrés parental (46,2\%). El dominio del PSI con mayor porcentaje de cuidadores con alto estrés fue el Sufrimiento Parental $(60,6 \%)$. La mayoría de los cuidadores prioriza las necesidades del niño con parálisis cerebral en detrimento de sus propias necesidades, siendo más de lo esperado $(90 \%)$. Estos resultados pueden respaldar las estrategias de intervención para minimizar el estrés parental.

Palabras clave: parálisis cerebral; niños; cuidadores; estrés

\section{Introduction}

The birth of a child with disability increases the demands for parental care and requires coping with the loss of the imagined child. From an ontogenetic point of view, the additional investment of time and resources for children with disabilities can be strongly associated with the identity of a "good parent." However, the prioritization of the child may occur in such exacerbated proportions that it may imply damage to the caregiver's own health (Dezoti et al., 2015; Fernández-Alcántara, et al., 2013).

The literature has described an increase in psychological disorders in caregivers of children with Cerebral 
Palsy (CP) (Dantas et al., 2012; Guyard, Michelsen, Arnaud \& Fauconnier; 2017; Omole et al., 2018; Wang, Huang \& Kong, 2017). This chronic condition results from a brain injury caused during brain formation, and is the most common cause of motor impairment in childhood. In addition to motor dysfunction, which affects posture and movement, other comorbidities may be associated with Cerebral Palsy, such as sensory deficiencies, epilepsy and cognitive impairment (Miller \& Bachrach, 2017).

Cerebral Palsy increases the burden of care tasks and the cost of parental investment. Parents or those who perform primary care often feel a lot of apprehension about the child's present and future while they need to decide on treatment and the financial cost to be spent on the child. Caregivers tend to perceive their own health as unsatisfactory, with muscle pain, symptoms of depression, reduced quality of life, and stress (Afonso, Ramos, França, Pontes \& Silva, 2016; Cunha, Ramos, Silva, Pontes, 2017; Dantas et al., 2012; Dezoti et al., 2015).

It is necessary to be attentive to those who provide primary care to children, as they are the main promoters of the interaction of children with their environment and their insertion in the most diverse contexts. For a child to become a healthy adult, there must be people who care for them, who feel confident to offer care, and who do so consistently (Afonso, Pontes \& Silva, 2018; Bronfenbrenner, 2011).

In this sense, the way caregivers deal with stressful events involved in parenting plays a key role in the dynamics of their families. The stress resulting from the exercise of parenting is called parental stress and is related to the self-assessment of the conformity between the real and the ideal performance in the role of parent, the resources that the parents consider available to exercise this role, as well as the expectations in relation to the child and the characteristics that he or she presents (Abidin, 1992; Ribeiro et al., 2013).

At adequate intensity, parental stress is a motivational variable that drives parents to seek resources to help them perform their parental role. Therefore, it does not harm the family system a priori, moreover, many families develop good skills to face adversity and have a successful family functioning (Abidin, 1992; Cunha, Pontes \& Silva, 2017; Ribeiro et al., 2013).

Some researches have described, for example, that caregivers of children with disabilities may feel rewarded when they perceive the renunciation of several of their interests in favor of the child, feel more resilient, and have a broader view of the world. In addition, the factors that initially triggered the stress reaction to disability may fail to elicit it when the family adapts to the new routines (Cunha, Pontes et al., 2017; Gregorutti \& Omote, 2015). On the other hand, very low levels of parental stress can be associated with parental neglect, little involvement with the child, and reduced investment in the role of parent (Abidin, 1992, 1995).

Very high or chronic stress, on the other hand, can lead the individual to exhaust his coping resources and to respond unsatisfactorily to the stressful event, generating dysfunctions that compromise parental well-being, sense of competence, and satisfaction with the parental role. In addition to these aspects, parental stress can impair the relationship with the child and increase the risk of developing behavioral and emotional problems in the child, as well as delays in the child's overall development. (Abidin, 1992, 1995; Freitas, 2015; Ribeiro et al., 2013; Silva, Cunha, Ramos, Pontes \& Silva, 2019; Stasiak et al., 2014).

Although the literature indicates damage to the health of caregivers of children with $\mathrm{CP}$, as well as a high rate of parental stress, the direct consequences of physical disability seem to be insufficient to explain the rates found. In this sense, we point out studies that verified the absence of correlations or the lack of association between parental stress and the level of severity of the child's motor impairment (Lima, 2016; Ribeiro et al., 2014).

In the study by Ribeiro et al. (2014) on parental stress with 223 caregivers of children with CP, it was verified that mothers of children with mild motor impairment (Levels I and II of the Gross Motor Function Classification System - GMFCS) showed greater parental stress in the dimension Difficult Child compared to caregivers of children with severe impairment (Levels IV and V of the GMFCS). In another study, with a methodological framework based on Grounded Theory, similar results were reported as shown in the following excerpt:

Women with children with mild motor impairment suffer more from the challenge of dealing with the children's emotional problems, aggressiveness, and learning difficulties. For those who have children with severe impairment, the most difficult thing is to deal with frequent illness (...) Ribeiro et al., 2016, p. 3210).

The production of knowledge about parental stress in caregivers of children with $\mathrm{CP}$ is of scientific and social relevance, since it can facilitate 
the identification of potential risk and protective factors to the developmental trajectories and the health of the family of the child with CP. Despite this, parental stress is a little studied theme in Brazil, particularly in the Brazilian Amazon. In view of the above, this study aimed to describe indicators of parental stress in primary caregivers of children with Cerebral Palsy in one of the states of the Brazilian East Amazon.

\section{Method}

This research was transversal and presented a quantitative approach. Regarding the objectives, it is a descriptive study with a data collection procedure of the survey type.

\section{Participants}

Participants included 132 caregivers of children with CP, living in the state of Pará. The selection criteria for the participants were: a) being 18 years old or older; b) being a family member or guardian of a child with CP aged from 1 to 12 years and 11 months, with a medical report attesting to the diagnosis and using a specialized care center for the person with multiple disabilities; c) being the main caregiver of the child for at least 1 year; and d) verbal and / or written skills that make it possible to respond to the instruments.

\section{Environment}

The survey was conducted in the Specialized Educational Service Centers maintained by the Association of Parents and Friends of Exceptional Children (APAE) in the municipalities of Belém, Castanhal, Marabá, and Santarém. These cities were selected because they are centers of their mesoregions, respectively Metropolitan Region of Belém, Northeast Pará, Southeast Pará, and Lower Amazon.

\section{Instruments}

- Sociodemographic Inventory (SDI): aims to characterize children with CP and their main caregivers. The SDI presents a list of objective questions related to the child's characteristics and clinical condition, such as sex, age, cause of CP, and whether there are health problems associated or in comorbidity; as well as the sociodemographic characteristics of the caregivers, including education, income, marital status, and occupation. The inventory was prepared by the research group of the Laboratory of Ecology of Development (LED) of the Graduate Program in Behavior Theory and Research at the Universidade Federal do Pará, UFPa.

- Gross Motor Function Classification System GMFCS: The instrument aims to classify the gross motor function of the person with CP according to their usual performance. The classification occurs in 5 levels: Level I corresponds to minimum disabilities, the person walks without limitation; Level II refers to walking without the aid of devices and crutches, but with some limitations, including jumping; Level III corresponds to walking with the aid of walkers or crutches; Level IV is characterized by marked limitations in walking even with the aid of devices, external assistance, and the use of a wheelchair is necessary to walk outside the home and in the community; Level V corresponds to severe limitations in movement and posture and includes the lack or little control of the head and trunk, even when using assistive technologies. The GMFCS was developed by Palisano et al. in 1997, and the Brazilian version by Silva et al. (2007) was used in this work.

As an example, the description of Level I and Level $\mathrm{V}$ for children before the age of 2 is presented:

LEVEL I: Babies sit on the floor, remain seated and leave this position with both hands free to manipulate objects. Babies crawl (on their hands and knees), pull themselves to stand and take steps while holding furniture. Babies walk between 18 months and 2 years of age without the need for devices to aid mobility. (...) LEVEL V: Physical disabilities restrict voluntary movement control. Babies are unable to maintain antigravity postures of the head and trunk in a prone and sitting position. Babies need adult assistance to roll (Silva et al., 2007, p. 03).

- Parental Stress Index (PSI/SF): aims to measure parental stress perceived by parents (Abidin, 1995). The PSI was used in its short form (PSI/ SF), which presents 36 items of the Likert scale type scored from 1 (fully agree) to 5 (fully disagree). The PSI/SF has 3 dimensions:

- Parental Distress (items 01 to 12): evaluates perceptions about the feelings experienced by parents in the role of father / mother, as exemplified by the items: "Since I had my child, I feel that I 
almost never have time to do the things I like "and

"I feel lonely and without friends."

- Parent-child Dysfunctional interaction (items 13 to 24): verifies the perceptions that parents have of whether or not their children are compatible with their expectations and whether their interactions with the child reinforce their role as a parent, as illustrated by the item: "My child rarely does things for me that make me happy."

- Difficult Child (items 25 to 36): verifies some behavioral characteristics of children that make them easier or more difficult to deal with. Among the items in this dimension are: "My child usually wakes up in a bad mood" and "I feel that my child is moody and easily upset,"

In the study by Ribeiro (2013), with a sample of 223 mothers of children and adolescents with CP, good levels of reliability of the instrument were found. Cronbach's alpha for the Parental Distress dimension was 0.813; for Parent-child Dysfunctional Interaction it was 0.741 , and for Difficult Child, 0.705 .

\section{Procedure}

\section{Data collection}

Initially, the project for this research was presented at a meeting of the Federation Council of APAEs of the State of Pará, as well as to the APAE management of the center cities in order to request support for the study and authorization to develop it. After a favorable feedback from the directors, the logistical preparation phase was conducted, which included the training of research assistants and the necessary procedures for the composition of a representative sample of the population of primary caregivers of children with CP cared for in the APAEs of the city centers.

For this, the sample size of participants was calculated (95\% confidence level) and then the sample size stratified by city. It is important to clarify that these procedures were made possible by the researchers' access to listings with the names of caregivers and children who met the selection criteria of the sample, together with their telephone contacts; information made available by the APAEs of each city.

In order to ensure that sample representativeness, we used the strategy of inviting all the people whose names were on the lists provided by the institution.
The invitations were made via telephone contact or in person in the waiting room of the care centers, which guaranteed a representative sample.

Data collection was conducted individually in a private room. The instruments were applied in 1 or 2 meetings, lasting around 20 to 30 minutes, in the sequence in which they were described in this article. The researcher read the instruments and recorded the answers given by the participant.

\section{Data analysis}

The data collected were analyzed with the help of the statistical application Statistica, version 6.0. Descriptive statistics were used for the data analysis, in order to quantify the frequency and the percentage obtained for each of the variables studied.

The responses to the PSI / SF items were converted into values from 1 to 5 , with 1 being assigned to the answers "I totally agree" and 5 to "I totally disagree". The due inversion of the values of the items that presented such requirement was conducted. The score for each dimension was then calculated from the sum of its items and then the total score of the PSI / SF.

According to Ribeiro (2013), scores equal to or higher than 94 on the total PSI / SF scale are worrisome. Although the instrument is not sufficient for a diagnosis, scores above the cutoff point indicate a high level of stress and the need for clinical evaluation. Thus, this study adopted the "High Stress" classification for scores higher than 94 and "Low Stress" for equal or lower scores. Regarding dimensions, the author used the following cutoff points: 33 for "Parental Distress"; 28 for "Parent-child Dysfunctional Interaction" and 37 for "Difficult child", these being also the values used in this study.

In addition, in order to understand in detail which aspects of the PSI / SF would favor high levels of parental stress, an item-by-item analysis of the instrument was conducted, identifying the sentences that described unpleasant feelings / sensations or stressful events. Then, the number of participants that had marked the answer option "I agree" or "I totally agree" for these statements was calculated.

\section{Ethical Considerations}

It is noteworthy that this research was developed according to the ethical principles of Resolution 510/2016 of the National Health Council / Brazilian Ministry of Health. The project of this investigation was evaluated by the Research Ethics Committee 
(Information Retrieved by the journal), having obtained a favorable opinion for its execution (approval $\mathrm{n}$. 20823313.0.0000.0018).

It should be noted that data collection started only after the reading and signing of the Free and Informed Consent Term (ICF) by those who agreed to participate in the survey. Information was provided on the purpose of the research, identity confidentiality, the voluntary nature of participation, and the guarantee of the right to refuse participation without any form of retaliation, in addition to other aspects relevant to the research, as well as clarification of doubts about the study.

\section{Results}

The results of this investigation will be presented in 2 sections. The first describes the profile of the caregivers who participated in the study and the children with $\mathrm{CP}$ under their care. The sample was characterized according to the variables: sex, age, marital status, family income, occupation, and family relationship with the child with Cerebral Palsy. Children were characterized by sex; age; and speech and motor disabilities.

The second section presents data on parental stress from 3 indicators: General PSI scale (Total Parental Stress); Parental Stress Dimensions (Parental Distress, Parent-child Dysfunctional Interaction, and Difficult Child); and potentially stressful perceptions and / or events.

\section{Profile of caregivers and children with Cerebral Palsy}

The sample consisted mostly of women ( $\mathrm{N}=128$, $97 \%$ ), of whom $93 \%$ were the mothers of the children $(\mathrm{N}=119)$. The average age of the caregivers was 31.8 years (min. 21 and max. 56), with $95 \%$ up to 35 years old. In relation to schooling, only $8.3 \%(\mathrm{~N}=11)$ had completed higher education or were in school. Most were married or living with a partner $(\mathrm{N}=96,72.7 \%)$ and had a family income of up to 2 minimum wages $(\mathrm{N}$ $=109,83 \%$ ). In addition, $83 \%$ were outside the formal or informal labor market.

Regarding the children under the care of the participants, 50\% were boys and 50\% girls and the average age was 6 years. Most of them presented severe motor impairment, since $61 \%$ needed the use of wheelchairs in all environments, in addition to requiring physical support to maintain the balance of the trunk and neck (Levels IV and V of the GMFCS). In addition, 79\% had difficulty speaking.

\section{Parental Stress}

The results of the analysis of the PSI / SF scores are shown in Table 2, for both the General Scale (Total Parental Stress) and the dimensions Parental Distress, Parent-child Dysfunctional Interaction, and Difficult Child.

There was a high number of caregivers with "High Stress" in the sample. In the PSI / SF general scale, $46.2 \%$ had scores above 94 . The analysis of the dimensions indicated that most of them presented "High Stress" for Parental Distress (60.6\%) and Parentchild Dysfunctional Interaction (51.5\%). The "Difficult Child" dimension was the only dimension that obtained a higher percentage of participants classified as "Low Stress."

Table 3 shows the results obtained for the instrument's sentences (PSI / SF items) that describe perceptions and / or potentially stressful events for most caregivers (50\% or more), organized according to the dimension to which they belong.

It was verified in all dimensions of the PSI / SF the existence of statements that contemplated $50 \%$ or more of the caregivers. The contents of these refer to: abandoning personal projects in favor of the child; difficulty of the caregiver in conducting activities other than those of a parental nature; overload of parental care; child's learning disability; skills or abilities of the child below the expectations of the caregiver; as well as low tolerance of the child to change or frustration.

\section{Discussion}

The main role of caregiver was exercised almost exclusively by the mother of the child with CP. Similar to what is put in the literature, the care and housekeeping tasks seem to be, in general, the main and only occupation of the mothers of children with $\mathrm{CP}$, since the insertion in the job market was low (Afonso et al., 2018; Baltor \& Dupas, 2013; Dezoti et al., 2015; Ribeiro et al., 2014).

It was found that an important portion of the sample had low family income and little education. The overload of care tasks associated with low family income can make it difficult for caregivers and their children to integrate more broadly into society. These aspects may even restrict access to health services and obtain technologies that favor accessibility and communication of children (Afonso et al., 2018; Baltor \& Dupas, 2013; Ribeiro et al, 2014; Souza, Freire, Cunha \& Silva, 2018). 
Table 1.

Sociodemographic characteristics of caregivers

\begin{tabular}{lc}
\hline \multicolumn{1}{c}{ Sex } & Nariables $(\%)$ \\
\hline Women & $128(97 \%)$ \\
Men & $04(03 \%)$ \\
\hline Level of education & $39(29.6 \%)$ \\
\hline No education or incomplete elementary school & $32(24.2 \%)$ \\
Complete elementary school & $50(37.9 \%)$ \\
Complete high School & $11(8.3 \%)$ \\
Complete or ongoing higher education & \\
\hline Marital status & $96(72,7 \%)$ \\
\hline Has a spouse / partner & $36(27,3 \%)$ \\
Single or divorced/separated or widower & $109(82.6 \%)$ \\
\hline Family Income & $13(09.8 \%)$ \\
\hline Until 02 minimum wages & $10(07.6 \%)$ \\
From 02 - 03 minimum wages & \\
More than 03 minimum wages & $109(82.6 \%)$ \\
\hline Occupation & $09(6.8 \%)$ \\
\hline Homemaker & $14(10.6 \%)$ \\
Paid activity in the Formal Labor Market &
\end{tabular}

Source. Developed by the authors

Table 2.

Frequency and Percentage of Caregiver Classified as "Low Stress" and "High Stress"

\begin{tabular}{lcc}
\hline & Low Stress & High Stress \\
\hline PSI/SF & $\mathrm{N} \%$ & $\mathrm{~N} \%$ \\
\hline Total Parental Stress & $71(53.8 \%)$ & $61(46.2 \%)$ \\
Parental Distress & $52(39.4 \%)$ & $80(60.6 \%)$ \\
Parent-child Dysfunctional Interaction & $64(48.5 \%)$ & $68(51.5 \%)$ \\
Difficult Child & $93(70.0 \%)$ & $39(30.0 \%)$ \\
\hline
\end{tabular}

Source. Developed by the authors

The financial aspect plays an important role in care and resizes the priority areas for spending on children with CP. In a situation of social vulnerability, the financial cost of treatment emerges as a source of anguish and concern, as expenses are high and the public system is unable to meet all demands (Baltor \& Dupas, 2013; Souza et al., 2018).
Regarding parental stress, a worrying situation was identified, since almost half of the caregivers presented "High Stress" on the general PSI / SF Scale (Total Parental Stress). Research that aimed to measure the parental stress of caregivers of children with CP, using PSI, found a percentage of participants with high parental stress similar to that observed in this 
Table 3.

PSI/SF Statements that describe unpleasant and/or stressful events for Caregivers

\begin{tabular}{lc}
\hline Statement & $\%$ \\
\hline Parental Distress & 90.15 \\
I give up my own things to take care of my children's needs more than I expected. & 59.09 \\
I feel trapped by my parenting responsibilities. & 50.70 \\
Since I had my child, I feel like I almost never have time to do the things I like. & 50.70 \\
\hline There are some things that bother me in my life. & 65.91 \\
\hline Parent-child Dysfunctional Interaction & 55.30 \\
\hline My child doesn't seem to learn as fast as most children. & 54.55 \\
\hline My child is not able to do things as much as I expected. & 66.70 \\
\hline Difficult Child & 64.30 \\
\hline When something happens that my child doesn't like, he or she reacts vigorously. \\
\hline
\end{tabular}

Source. Designed by the authors

study (Lima et al., 2016; Omole et al. 2018; Ribeiro et al., 2014).

Caregivers who score above the PSI cutoff point are likely to experience a clinically relevant intensity of parental stress. Therefore, they should be referred to professional care services and, possibly, there is a need for clinical monitoring (Abidin,1992).

The impacts of experiencing intense and / or chronic parental stress can be perceived in the short and long term and are usually associated with impairments in psychological functioning, quality of life, and social support for parents. High parental stress can also impair the quality of parent-child relationships, the sense of competence, and the sense of parental wellbeing (Cunha, Ramos et al. 2017; Ribeiro et al, 2014; Silva et al., 2019; Stasiak et al., 2014).

These aspects can enhance the child's behavioral problems, which in turn feed on parental stress. The high stress rate of parents can favor the child's delayed development and the development of behavioral and emotional problems (Cunha, Ramos et al. 2017; Freitas, 2015; Silva et al., 2019; Stasiak et al., 2014).

Regarding the dimensions of the PSI / SF, there was a higher concentration of caregivers with "High Stress" in the dimensions Parental Distress and Parent-child Dysfunctional Interaction. A result that was similar to those found in national surveys conducted by Cunha, Pontes et al. (2017), Lima et al. (2016), and Ribeiro et al. (2014), who also obtained the highest percentages of high parental stress in these dimensions.

The statements of the items that compose the Parental Distress dimension refer mainly to the perception and feelings of caregivers about their role as a parent, as well as the restrictions that this role can generate for the performance of other roles, besides the characteristics related to the personality of the parents, such as depression. Therefore, those who presented high stress in this dimension were probably experiencing feelings of low competence and satisfaction with the parental role (Ribeiro et al., 2014).

Regarding the dimension Parent-child Dysfunctional Interaction, high levels of stress suggest that the caregiver has been feeling disappointed or rejected by the child; or that the interactions between them are in disagreement with parental expectations and do not reinforce them in their role as a parent (Minetto, 2010). Lima et al. (2016) when considering that this dimension refers to the expectations of parents that their real child is compatible with the image they had idealized, hypothesize that the more distinct the skills that caregivers attribute to their children from those they desire, the greater the difficulty in accepting the disability.

The items of the dimensions Parental Distress and Parent-child Dysfunctional Interaction were mainly responsible for obtaining scores above the cutoff point for Total Parental Stress. A joint analysis of these dimensions suggests that the exercise of the parental 
role has required efforts beyond resources or what was expected from the caregivers. It is interesting to point out that some of the factors that may have contributed to the high percentage of caregivers with "High Stress" in these dimensions may have contributed to the fact that the Difficult Child dimension obtained the lowest percentage.

The Difficult Child dimension assesses characteristics of the child that make them easier or harder to deal with, such as distraction, hyperactivity, demandingness, and mood (Stasiak et al., 2014). Given the large number of children with severe speech and motor disabilities, it is possible that the child's limitations may facilitate the management of externalizing behaviors while making it difficult to establish communication and interactions between the caregiver and their child.

In addition, due to the marked physical impairment of the child with $\mathrm{CP}$, the child's emotional and behavioral problems may receive less attention from caregivers or be less evident due to the child's own motor and communication limitations. In contrast, greater motor capacity can make the behavior considered challenging and inconvenient more explicit, as well as the difficulty in following rules (Ribeiro et al., 2014; Ribeiro et al., 2016).

The results related to the PSI / SF sentences that describe unpleasant feelings / sensations or potentially stressful events bring evidence in this same direction. The joint analysis of the contents seems to indicate that part of the sample realized that the role as a parent has required a very high investment from himself or herself. High parental investment associated with low self-esteem, feelings of helplessness, and lack of financial resources can raise stress to harmful levels, impair satisfaction with the parental role, and generate feelings of incompetence (Dantas et al., 2012; Dezoti et al., 2015; Ribeiro et al., 2014).

The scarcity of studies that seek to measure parental stress using the PSI / SF in Brazil makes it impossible to deepen comparative analyzes between the results. Nevertheless, some indications can be pointed out, such as the predominance of parental stress due to the perception of low competence and satisfaction with the parental role, as well as frustrated expectations regarding the imagined / real child.

According to Urie Bronfenbrenner (2011), the performance of the primary caregiver is related to their assessments of their ability to function and their role as parent. This, in turn, is related to external factors such as time spent caring for oneself and the needs of the child, as well as the quality of services and social support received.

The physical and emotional exhaustion associated with poor self-directed care weakens the caregiver and it can make child care more difficult in the future (Afonso et al., 2016; Sawyer et al., 2011). Considering the negative impacts of the high levels of stress of caregivers on the development of family members, it is necessary to continue making efforts to investigate variables that can mediate levels of parental stress. This would allow the planning of actions better suited to the demands of this audience.

The perception of low social support was identified as one of the variables related to high levels of parental stress. In this sense, informal and formal social support play an important role in family adaptation processes and can act as a protective factor for families of children with CP. As care tasks, fears, and concerns can be shared, besides performing leisure activities and having specialized professional support available, the physical and emotional overload is minimized (Afonso et al., 2016; Cunha et al., 2017; Dantas et al., 2012; Sawyer et al. 2011; Souza et al., 2018).

According to Afonso et al. (2016, p. 468) "parental care in cerebral palsy can be understood from adaptations that go beyond family efforts, requiring greater psychosocial support and a support network capable of minimizing adversity." The authors added that the task of caring for children with CP becomes difficult in part due to the deficits present and in large part due to the lack of services that are sensitive to the needs of caregivers.

On the other hand, in the investigation by Afonso et al. (2018), caregivers of children with severe CP (GMFCS level V) had higher social satisfaction than those with less impairment, especially in family social activities. Such results challenge a possible cause and effect relationship between the severity of the child's limitations and the psychosocial and emotional dysfunctions of their caregivers.

Cunha et al. (2017) when investigating caregivers of children with $\mathrm{CP}$ who had low levels of parental stress, identified several protective factors. Some of these are more personal, such as positive expectations regarding the child's development and positive representation of the child; spirituality; coping with crisis situations through initiative, creativity, and focus on the child's well-being. And more contextual ones like access to information, social and economic resources, and rehabilitation. 
Coping with adverse conditions such as $\mathrm{CP}$ permeates the identification by the family of its needs, and public actions aimed at accessibility and health promotion (Baltor \& Dupas, 2013; Cunha et al., 2017; Souza et al., 2018). In addition to including primary caregivers in the care of children with $\mathrm{CP}$, the results suggest the need for family-centered actions to promote the development of appropriate coping strategies, skills to cope with their own difficulties in the role of parent and to welcome the child, besides expanding the social support network and facilitating access to assistive technologies.

In view of the situation presented in this study, it is essential that health, education, and social assistance professionals be attentive to the stress of parents of children with CP. However, this study has methodological limitations that require caution regarding its generalization, among them the number of participants, and the fact that the sample consisted of users from philanthropic institutions.

Such aspects may have reflected in a psychosocial and parental stress profile distinct from those of families belonging to another socioeconomic strata, with access to the private network of health and education services, for example. Another limitation refers to the assessment of parental stress, considering that the instrument used does not include everyday aspects of caring for a child with CP.

From the results found and the limitations of this study, a range of lines of investigation about parental stress in caregivers of children with CP is presented. Studies using inferential statistics to analyze the possible relationship between parental stress and the variables social support, marital satisfaction, paternal involvement, and sociodemographic characteristics, as well as qualitative studies that describe risk and protective factors for clinical parental stress are investigative paths for the production of knowledge of scientific and social relevance on the subject. It is also identified the relevance of comparative research on indicators of parental stress before and after intervention programs, among caregivers from different Brazilian states, social strata, and children with typical development.

Despite its limitations, it is estimated that this study may contribute to a better understanding of parental stress and, consequently, stimulate reflections and subsidies for the planning of new research and actions more appropriate to the demands of the investigated public.

\section{References}

Abidin, R. R. (1992). The determinants of parenting behavior. Journal of Clinical Child Psychology, 21(4), 407-412. doi:10.1207/s15374424jccp2104_12

Abidin, R. R. (1995). Parenting Stress Index. Odessa, FL: Psychological Assessment Resources.

Afonso, T., Pontes, F. A. R., \& da Costa Silva, S. S. (2018). Apoio e satisfação social de cuidadores primários de crianças com paralisia cerebral [Social support and satisfaction of primary caregivers of children with cerebral palsy]. Revista Psicologia-Teoria e Prática, 20(2), 147-160. doi: 10.5935/1980-6906/ psicologia.v20n2p161-174

Afonso, T., Ramos, M. F. H., França, I. L., Pontes, F. A. R., \& Silva, S. S. D. C. (2016). Cuidado Parental à Criança com Paralisia Cerebral: uma Revisão Sistemática da Literatura. Revista Brasileira de Educaşão Especial, 22(3), 455-470. doi: https://doi. org/10.1590/S1413-65382216000300011

Baltor, M. M. R., \& Dupas, G. (2013). Experiências de famílias de crianças com paralisia cerebral em contexto de vulnerabilidade social. Rev. LatinoAm. Enfermagem, 21(4), 08. Retrieved from http:// www.scielo.br/pdf/rlae/v21n4/pt_0104-1169rlae-21-04-0956.pdf 26 de fev 2015

Bronfenbrenner, U. (2011). Bioecologia do desenvolvimento bumano: tornando os seres humanos mais bumanos. (A. Carvalho-Barreto, Trad.). Porto Alegre, Brasil: Artmed. (Original publicado em 2005).

Cunha, K. D. C., Pontes, F. A. R., \& Silva, S. S. D. C. (2017). Children with Cerebral Palsy of Little Stressed Parents. Revista Brasileira de Educação Especial, 23(1), 111-126. doi: 10.1590/s1413-65382317000100009

Cunha, K. D. C., Ramos, M. F. H., Silva, S. S. D. C, \& Pontes, F. A. R. P. (2017). Estresse parental e paralisia cerebral [Parental stress and cerebral palsy]. Psicologia, Saúde \& Doenças, 18(2), 433-450. doi: 10.15309/17psd180212

Dantas, M. S. A., Pontes, J. F., Assis, W. D., \& Collet, N. (2012). Facilidades e dificuldades da família no cuidado à criança com paralisia cerebral [Family's abilities and difficulties in caring for children with cerebral palsy]. Revista Gaúcha de Enfermagem, 33(3), 73-80. doi:10.1590/ S1983-14472012000300010 
Dezoti, A., Cosvoski Alexandre, A., \& de Souza Freire, M., Alves das Mercês, N., \& de Azevedo Mazza, V. (2015). Apoio social a famílias de crianças com paralisia cerebral [Social support to the families of children with cerebral palsy]. Acta Paulista de Enfermagem, 28 (2), 172-176. doi: 10.1590/1982-0194201500029

Fernández-Alcántara, M., García-Caro, M. P., Berrocal-Castellano, M., Benítez-Feliponi, Á., Robles-Vizcaíno, C., \& Laynez-Rubio, C. (2013). Experiencias y cambios en los padres de niños con parálisis cerebral infantil: estudio cualitativo [Experiences and changes in parents of children with infant cerebral palsy: a qualitative study]. An. Sist. Sanit. Navar, 36(1), 9-20. doi: 10.4321/ S1137-66272013000100002

Freitas, L. S. G. (2015). Estresse Materno e Desenvolvimento de Crianças Moradoras em Contexto Ribeirinho e Urbano de Belém - Pará (Dissertação de Mestrado, Programa de Pós-graduação em Teoria e Pesquisa do Comportamento, Universidade Federal do Pará, Belém). Retrieved from http://ppgtpc.propesp. ufpa.br/ARQUIVOS/dissertacoes/Lilianne $\% 20$ Freitas\%202015.pdfFreitas LSG.

Gregorutti, C. C., \& Omote, S. (2015). Relação entre inclusão escolar de crianças com paralisia cerebral e estresse dos cuidadores familiares [Relationship between school inclusion of children with cerebral palsy and stress of family caregivers]. Revista Psicologia-Teoria e Prática, 17(1), 136-149. doi: 10.15348/1980-6906/psicologia.v17n1p136-149.

Guyard, A., Michelsen, S. I., Arnaud, C., \& Fauconnier, J. (2017). Family adaptation to cerebral palsy in adolescents: A European multicenter study. Research in developmental disabilities, 61, 138-150. doi: 10.1016/j. ridd.2016.11.010

Lima, M. B. S., Cardoso, V. D. S., \& Silva, S. S. D. C. (2016). Parental Stress and Social Support of Caregivers of Children With Cerebral Palsy. Paidéia (Ribeirão Preto), 26(64), 207-214. doi: 10.1590/1982-43272664201608

Miller, F., \& Bachrach, S. J. (2017). Cerebral palsy: A complete guide for caregiving. JHU Press.

Minetto, M. F. J. (2010). Práticas educativas parentais, crenças parentais, estresse parental e funcionamento familiar de pais de crianças com desenvolvimento típico (Tese de doutorado, Universidade Federal de São Carlos, São
Carlos). Retrieved from https://repositorio.ufsc. br/xmlui/handle/123456789/94159

Omole, J. O., Adegoke, S. A., Omole, K. O., Mbada, C. E., Adedeji, G. A., \& Adeyemi, O. A. (2017). Levels, Correlates, and Predictors of Stress and Caregiver Burden among Caregivers of Children with Cerebral Palsy in Nigeria. Journal of Pediatric Neurology. doi: 10.1055/s-0037-1612639

Ribeiro M. F. M. (2013). Estresse parental em mães de bebês, crianças e adolescentes com paralisia cerebral (Tese de Doutorado, Programa de Pós Graduação em Ciências da Saúde, Universidade Federal de Goiás). Retrieved from http://repositorio.bc.ufg.br/tede/ handle/tde/2982

Ribeiro, M. F. M., Porto, C. C. \& Vandenberghe, L. (2013). Estresse parental em famílias de crianças com paralisia cerebral: revisão integrativa [Parental stress in families of children with cerebral palsy: an integrative review]. Revista Ciência \& Saúde Coletiva, 18(6), 1705-1715, Retrieved from http://www.scielosp.org/pdf/csc/v18n6/22.pdf

Ribeiro, M. F. M., Sousa, A. L. L., Vandenberghe, L., \& Porto, C. C. (2014). Parental stress in mothers of children and adolescents with cerebral palsy. Revista Latino-Americana Enfermagem, 22(3), 440-447. doi:10.1590/0104-1169.3409.2435

Ribeiro, M., F., M., Vandenberghe, L., Prudente, M., Oliveira, C., da Silva Carvalho Vila, V., \& Porto, C. C. (2016). Paralisia cerebral: faixa etária e gravidade do comprometimento do filho modificam o estresse e o enfrentamento materno [Cerebral Palsy: how the child's age and severity of impairment affect the mother's stress and coping strategies]. Revista Ciência \& Saúde Coletiva, 21(10). 3203-3212. doi: 10.1590/1413-812320152110.17352016

Sawyer, M. G., Bittman, M., La Greca, A. M., Crettenden, A. D., Borojevic, N., \& Raghavendra, P., et al. (2011). say? Developmental Medicine \& Child Neurology, 53, 338-343.

Silva, D. B. R., Pfeifer, L. I. \& Funayama, C. A. R. (2007). GMFCS - E \& R. Sistema de Classificação da Função Motora Grossa Ampliado e Revisto. Retrieved from http://motorgrowth.canchild.ca/en/ GMFCS/resources/PORTUGUESE_corrigidoFINALMay12.pdf

Silva, I. C. P., Cunha, K. C., Ramos, E. M. L. S., Pontes, F. R. A, \& Silva, Simone S. C. (2019). Estresse 
parental em famílias pobres. Psicologia em Estudo, 24, e40285. doi:10.4025/1807-0329e40285.

Souza, Y. L. D. C., Freire, V. R. B. P., Cunha, K. C., \& Silva, S. S. C. (2018). Rede de Suporte Social de Mães de Crianças com Paralisia Cerebral em Belém do Pará. Mudanças-Psicologia da Saúde, 26(1), 1-10. Retrieved from https://www.metodista.br/ revistas/revistas-ims/index.php/MUD/article/ view/8011/6360

Stasiak, G. R., Weber, L. N. D., \& Tucunduva, C. (2014). Qualidade na interação familiar e estresse parental e suas relações com o autoconceito, habilidades sociais e problemas de comportamento dos filhos [Quality in Family Interaction and Parental Stress and its Relationships with Children's Self-Concept, Social Skills and Behavior Problems]. Psico, 45(4), 494-501. doi: http://dx.doi. org/10.15448/1980-8623.2014.4.15846

Wang, Y., Huang, Z., \& Kong, F. (2017). Parenting stress and life satisfaction in mothers of children with cerebral palsy: The mediating effect of social support. Journal of health psychology, 1-10. doi: $10.1177 / 1359105317739100$

Recebido em: 07/12/2018 Reformulado em: 23/03/2020

Aprovado em: 24/07/2020 
About the authors:

Mayara Barbosa Sindeaux Lima - B.A in Psychology from the Universidade Federal do Pará (UFPA) and PhD in Behavior Theory and Research from UFPA. Currently, she is an associate professor at the Universidade Federal do Sul e Sudeste do Pará (Unifesspa) and Vice-director of the School of Psychology (FAPSI/Unifesspa). She develops research in the areas of Psychology of Development and Health. Mother of Felipe Sindeaux. L. S. Lima

ORCID: https://orcid.org/0000-0002-7788-0849

E-mail:mayarasindeaux@unifesspa.edu.br

Edson Marcos Leal Soares Ramos - PhD in Production Engineering from the Universidade Federal de Santa Catarina (2003) and Bachelor in Statistics from the Universidade Federal do Pará (1994). Full professor at the undergraduate level and at the Graduate Program in Public Security of the Universidade Federal do Pará, and collaborating professor at the Universidade de Cabo Verde in the Graduate Program in Public Security. Counselor of the Brazilian Public Security Forum.

ORCID: https://orcid.org/0000-0001-5425-8531

E-mail: ramosedson@gmail.com

Fernando Augusto Ramos Pontes - PhD in Psychology from the Universidade de São Paulo and Post-doctorate from the Universidade de Brasília (2002) and the Technischen Universität Dortmund, Germany (2012). Full professor at the Universidade Federal do Pará, linked to the Behavior Theory and Research Center and the Behavior Theory and Research Graduate Program, and professor at the Graduate Program in Public Security of the Universidade Federal do Pará.

ORCID: https://orcid.org/0000-0001-9569-943X

E-mail: farp1304@gmail.com

Simone Souza da Costa Silva - PhD in Psychology from the Universidade de Brasília (2006) and postdoctoral degree in Rehabilitation Sciences from the Dortmund Universität, Germany (2012). Professor and associate director at the Behavior Theory and Research Center (NTPC/UFPA). Professor at the Behavior Theory and Research Graduate Program (PPGTPC), and at the Graduate Program in Public Security of the Universidade Federal do Pará (PPGSP). ORCID: https://orcid.org/0000-0003-0795-2998

E-mail:symon.ufpa@gmail.com

\section{Contact:}

Universidade Federal do Sul e Sudeste do Pará. Unidade III, Institute of Health and Biological Studies Av. dos Ipês, s/n, Cidade Jardim

Marabá-PA, Brasil

CEP: 68500-000 